\title{
CONTROL OF BRASSICA APHID AND BLUE-GREEN LUCERNE APHID WITH CHLORPYRIFOS
}

\author{
C. J. SHARPE and B. N. MacDIARMID \\ Ivon-Watkins-Dow Ltd, Dunedin and New Plymouth.
}

\section{Summary}

In four trials (two aerial) on brassica aphid (Brevicoryne brassicae) and four on the blue-green lucerne aphid (Acyrthosiphon kondoi), chlorpyrifos at 0.125 and $0.188 \mathrm{~kg} / \mathrm{ha}$ gave $95-100 \%$ control. The speed of kill and final level of control was similar to that achieved with demeton-S-methyl or diazinon. Lucerne (Medicago sativa) yields were doubled as a result of lucerne aphid control sativa) weeks after treatment when conditions for continuous breeding and dispersal were suitable.

\section{INTRODUCTION}

In February 1975 a moderate outbreak of brassica aphid (Brevicoryne In February 1975 a moderate in field brassicas presented an opportunity to obtain trial data and field assessment on the efficacy of the broad spectrum insecticide chlorpyrifos as an aphicide. These studies were extended to lucerne (Medicago sativa) during summer 1976 when an outbreak of the recently introduced blue-green lucerne aphid (Acyrthosiphon kondoi) occurred.

\section{METHOD}

Four brassica aphid trials were laid during February 1975 on stands of $20-40 \mathrm{~cm}$ high bulbous swedes and $1 \mathrm{~m}$ high kale growing in South Otago. Two were six replicate, small plot $(4 \times 5 \mathrm{~m})$ trials using a precision sprayer applying 75 litres/ha of spray mixture. The other two were single replicate aerial trials ( $2 \mathrm{ha} /$ treatment) using a fixed wing aircraft applying 77 litres/ha. Small untreated areas were retained in the latter trials.

Of the four lucerne aphid trials reported, two were laid down on 11 February 1976 in Waverley and the other two on 24 March in Hastings. The trials were two replicate with large plots $(5-6 \mathrm{~m} \times 20 \mathrm{~m})$ and $2 \mathrm{~m}$ wide untreated margins, laid with a hand-held or wheel-mounted spray boom applying 220 litres/ha through 8003 fan nozzles at $200 \mathrm{kPa}$. At each location, one trial was laid on $40-60 \mathrm{~cm}$ high lucerne and one on lucerne $2-4 \mathrm{~cm}$ high.

Assessment of populations of both aphid species were made before and regularly after treatment. Brassica aphids were assessed by selecting young leaves (10 per plot, 50 in aerial trials) which showed obvious evidence of infestation viz. chlorosis and cupping, dead or live aphids and frass. In the lucerne aphid trials, 10 shoots per plot were selected at random and the top half of each shoot assessed for live aphids using the logarithmic-type scale below. The effect of the insecticides on ladybird populations in lucerne was also noted.

One lucerne trial at Waverley was harvested by cutting five random $0.15 \mathrm{~m}^{2}$ quadrats per plot and from each adjacent untreated strip.

Proc. 29th N.Z. Weed and Pest Control Conf. 


\section{Crop Pests}

$\begin{array}{ccc}\text { Rating } & \text { Brassica aphid } & \text { Lucerne aphid } \\ 0 & 0 & 0 \\ 1 & 1-5 & 0-3 \\ 2 & 6-50 & 4-10 \\ 3 & 51-250 & 11-20 \\ 4 & 251-500 & 21-50 \\ 5 & 500 & 50\end{array}$

\section{RESULTS AND DISCUSSION}

Brassica aphid

The brassica aphid control achieved in the small scale trials are summarised in Table 1. Pre-treatment counts are shown under "untreated-0 days." Chlorpyrifos at 0.125 and $0.188 \mathrm{~kg} / \mathrm{ha}$ gave excellent control, equivalent to standard rates of demeton-S-methyl, such that 11 days after treatment $95 \%$ of the previously infested leaves were aphidfree. This compared with only $3 \%$ in the untreated plots. The aphicidal activity of chlorpyrifos was confirmed in the aerial application to large areas (Table 2).

TABLE 1: PERCENT LEVEL OF BRASSICA APHID INFESTATION IN SMALL SCALE TRIALS

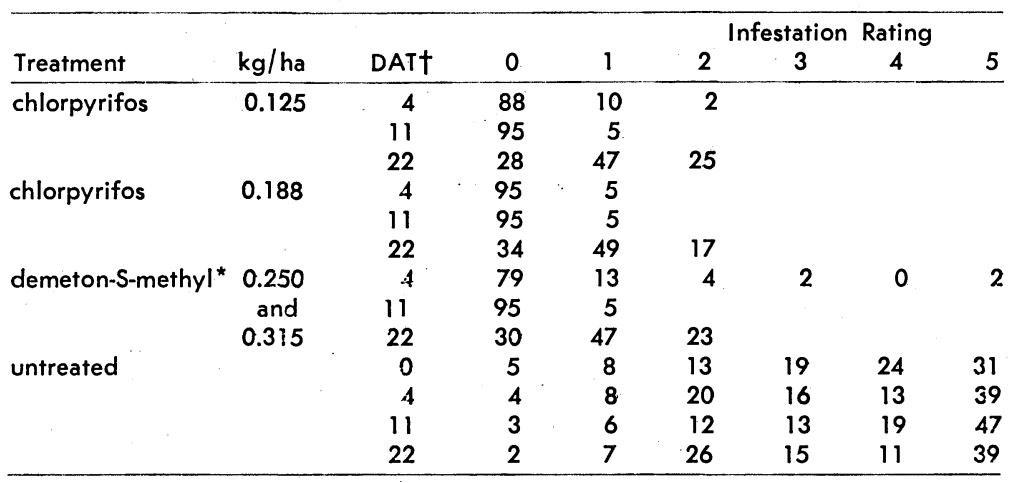

* - Mean of both rates, each in one trial

DAT† - Days after treatment

TABLE 2: PERCENT LEVEL OF BRASSICA APHID INFESTATION IN AERIAL TRIALS

\begin{tabular}{lrrrrrrrr}
\hline & & \multicolumn{7}{c}{ Infestation Rating } \\
Treatment & $\mathrm{kg} / \mathrm{ha}$ & $\mathrm{DAT}$ & \multicolumn{1}{c}{0} & $\mathbf{1}$ & $\mathbf{2}$ & $\mathbf{3}$ & $\mathbf{4}$ & 5 \\
\hline chlorpyrifos & 0.125 & 4 & 95 & 5 & & & & \\
& & 11 & 100 & & & & & \\
& & 19 & 100 & & & & & \\
untreated & & 26 & 25 & 47 & 26 & 2 & & 37 \\
& & 0 & 5 & 8 & 15 & 24 & 11 & 37 \\
& & 4 & & & 10 & 13 & 26 & 51 \\
& 26 & 5 & 4 & 10 & 10 & 14 & 57 \\
\hline
\end{tabular}


Neither insecticide prevented aphid reinfestation which was evident in all trials 22-26 days after treatment. Ho'wever, reinfestation levels did not reach those occurring in the untreated areas, the onset of cold wet weather dramatically reducing populations thereby preventing further damage.

\section{Lucerne Aphid}

The blue-green lucerne aphid also proved particularly susceptible to chlorpyrifos as a summary of the trials in Table 3 shows. Diazinon $0.5 \mathrm{~kg} / \mathrm{ha}$ (and demeton-S-methyl $0.175 \mathrm{~kg} / \mathrm{ha}$ in two trials) was also very effective, but maldison gave poor results. There was some indication that the higher rate of chlorpyrifos was required for tall lucerne stands.

TABLE 3, PERCENT LEVEL OF LUCERNE APHID INFESTATION IN WAVERLEY AND HASTINGS TRIALS

\begin{tabular}{|c|c|c|c|c|c|c|c|c|}
\hline \multirow[b]{2}{*}{ Treatment } & \multirow[b]{2}{*}{$\mathrm{kg} / \mathrm{ha}$} & \multirow[b]{2}{*}{ DAT } & \multirow[b]{2}{*}{0} & \multicolumn{4}{|c|}{ Infestation rating } & \multirow[b]{2}{*}{5} \\
\hline & & & & 1 & 2 & 3 & 4 & \\
\hline \multirow[t]{3}{*}{ chlorpyrifos } & 0.125 & 2 & 98 & 1 & 1 & & & \\
\hline & & 6 & 98 & 2 & & & & \\
\hline & & 13 & 20 & 40 & 20 & 20 & & \\
\hline \multirow[t]{3}{*}{ chlorpyrifos } & 0.188 & 2 & 100 & & & & & \\
\hline & & 6 & 100 & & & & & \\
\hline & & 13 & 40 & 35 & 15 & 10 & & \\
\hline \multirow[t]{3}{*}{ diazinon } & 0.500 & 2 & 100 & & & & & \\
\hline & & 6 & 100 & & & & & \\
\hline & & 13 & 30 & 45 & 10 & 15 & & \\
\hline \multirow[t]{2}{*}{ maldison } & 0.350 & 2 & 0 & 10 & 20 & 30 & 40 & \\
\hline & & 6 & 20 & 30 & 40 & 10 & & \\
\hline \multirow[t]{3}{*}{ untreated } & & 0 & 7 & 10 & 30 & 30 & 20 & 3 \\
\hline & & 6 & 13 & 20 & 33 & 27 & 7 & \\
\hline & & 13 & 0 & 30 & 20 & 30 & 20 & \\
\hline
\end{tabular}

Reinfestation by winged adults from outside the plots was evident 13 days after treatment, but observations made where whole paddocks were treated, suggest that protection could extend up to 21 days.

Both Hastings trials contained larval populations of the predator ladybird Coccinella leorina as high as $500 / \mathrm{m}^{2}$ and in one trial on young 'Saranac' lucerne they were probably responsible for eliminating the lucerne aphid in the untreated areas. All effective aphicides also killed the ladybird larvae.

The yields from one lucerne trial, which was sprayed 1 week after baling ( 2 weeks from last cut) and resprayed overall 2 weeks later with chlorpyrifos $0.15 \mathrm{~kg} / \mathrm{ha}$, are shown 5 weeks after baling in Table 4 . The yields had doubled in the treated areas during this period, representing a $20 \mathrm{bale} / \mathrm{ha}$ increase.

TABLE 4: EFFECT OF LUCERNE APH.ID CONTROL ON LUCERNE YIELDS

\begin{tabular}{lcr}
\hline Treatment & $\mathrm{kg} / \mathrm{ha}$ & $\%$ increase \\
\hline chlorpyrifos & 0.125 & 94 \\
chlorpyrifos & 0.250 & 91 \\
diazinon & 0.500 & 104 \\
untreated \pm SE & & $1300 \pm 164 \mathrm{~kg} \mathrm{DM} / \mathrm{ha}$ \\
CV \% & & 19 \\
\hline
\end{tabular}




\section{Crop Pests}

The results presented show that chlorpyrifos is very effective at low rates for controlling aphids on fast-growing, leafy crops such as brassicas and lucerne.

\section{ACKNOWLEDGEMENTS}

During the lucerne aphid outbreak, the authors were most grateful to Messrs D. Robertson, Waverley; J. Esson, DSIR Auckland, and W. Kain, MAF, Palmerston North; for assistance. 